\title{
Clustering of malformations in the families of South American oral cleft neonates
}

\author{
Beatriz G Menegotto, Francisco M Salzano
}

\begin{abstract}
The relatives of 741 newborn children with nonsyndromic cleft lip with or without cleft palate $(C L \pm P)$, of 115 with isolated cleft palate (CP), and of equal numbers of appropriate controls were screened for the presence of the same or different malformations. The main findings were as follows. (1) The frequency of familial cases of $C L \pm P$ $(17.3 \%)$ was much higher than the prevalence of this malformation among the relatives of controls $(0.5 \%)$. (2) The sibs of $C L \pm P$ subjects showed a higher prevalence of this condition than their parents $(2.9 \% v 1.6 \%)$. (3) The degree of genetic determination of this condition should be high (70 to $\mathbf{7 4 \%}$ ), and the data in general favour a multifactorial model of inheritance, with different thresholds between sexes. However, the action of dominant genes cannot be excluded since selection or dominant genes or both could be postulated to explain the parent/sib difference. (4) The frequency of other malformations was also significantly raised in the families of $C L \pm P$ probands, as compared to controls $(12.1 \% v 6.2 \%)$. (5) The prevalence of these other malformations was higher among sibs $(1.6 \%)$ than parents $(0.7 \%)$ of $C L \pm P$ babies. (6) $A$ general susceptibility to malformations and different exposure to selective agents may explain these latter findings. (7) None of the comparisons involving CP children yielded significant results.
\end{abstract}

The fact that cleft lip with or without cleft palate $(C L \pm P)$ and isolated cleft palate (CP) occur more frequently in the families of subjects with these malformations than in the general population is well known, the independence between these entities having been established in the 1940 s. ${ }^{1}$ Recent reviews

Departamento de Genética, Instituto de Biociências, UFRGS, Caixa Postal 1953, 90001 Porto Alegre, RS, Brazil.

B G Menegotto, F M Salzano

Correspondence to Professor Salzano.

Received for publication 1 March 1990.

Revised version accepted for publication 3 July 1990. on the genetics of these conditions can be found in Bear $^{2}$ and Fraser. ${ }^{3}$ However, the causes of liability to these conditions are far from clear, especially the variation in risk according to the type of proband considered (whether they are males or females, and have a more or less severe malformation), a question that is vital for the establishment of the appropriate model of disease liability. ${ }^{47}$ Estimates of the degree of genetic determination of these entities have also been quite variable. ${ }^{5-12}$ Another problem is the relationship between the susceptibility to these conditions and to other malformations, excluding the syndromes of which $\mathrm{CL} \pm \mathrm{P}$ and $\mathrm{CP}$ are a part. Here again, there are conflicting results and interpretations. ${ }^{12-14}$ Therefore, we decided to investigate certain aspects of these questions as part of a larger study, which included an epidemiological search and the analysis of the association between these anomalies and fetal death. ${ }^{15} 16$

\section{Subjects and methods}

The data were obtained through the Latin American Study of Congenital Malformations (ECLAMC, Estudio Colaborativo Latinoamericano de Malformaciones Congénitas). This is a clinical-epidemiological programme of the case control type, based in hospitals, the aim of which is the investigation of congenital defects detected in the neonatal period. This study has been operating in several South American countries since 1967. All babies born in the hospitals which participate in the programme (at present there are 82 hospitals, located in 10 countries) are examined at birth by a trained paediatrician, and minor as well as severe malformations are described in detail. Information about risk factors and family histories are obtained by this physician directly from the mother in the postpartum period. Each malformed child is allocated a control, which is the first normal baby of the same sex born in that hospital after the malformed one.

All cases of $C L \pm P$ and of $C P$ ascertained during the period 1967 to 1981 who had no associated anomalies were selected for the study, and the data were transferred to the files of a PC-XT microcomputer, using the dbase III plus program. Subsequently, they were subjected to standard statistical procedures. 
Table 1 Prevalence of the same or different types of malformation among the relatives of probands and controls.

\begin{tabular}{|c|c|c|c|c|c|c|c|c|}
\hline \multirow{2}{*}{$\begin{array}{l}\text { Degree of } \\
\text { relationship }\end{array}$} & \multicolumn{2}{|c|}{ Relatives with $\mathrm{CL} \pm \mathrm{P}^{*}$} & \multicolumn{2}{|c|}{ Relatives with $\mathrm{CP}^{*}$} & \multicolumn{4}{|c|}{ Relatives with other malformations ${ }^{*}$} \\
\hline & $\mathrm{CL} \pm \mathrm{P}$ & Control & $\mathbf{C P}$ & Control & $\mathrm{CL} \pm \mathrm{P}$ & Control & $\mathrm{CP}$ & Control \\
\hline $\begin{array}{l}1 / 2 \text { (parents) } \\
\text { (sibs) } \\
1 / 4 \\
1 / 8 \\
1 / 16 \\
1 / 32 \\
<1 / 32 \\
\text { Unspecified } \\
\text { Total } \\
\text { No of families } \\
\text { No of families with }\end{array}$ & $\begin{array}{r}24 \\
37 \dagger \\
34 \\
35 \\
19 \\
4 \\
3 \\
3 \\
159 \\
741\end{array}$ & $\begin{array}{r}0 \\
0 \\
1 \\
4 \\
2 \\
0 \\
0 \\
0 \\
7 \\
741\end{array}$ & $\begin{array}{r}0 \\
1 \\
1 \\
1 \\
0 \\
0 \\
0 \\
0 \\
3 \\
115\end{array}$ & $\begin{array}{r}0 \\
0 \\
0 \\
0 \\
0 \\
0 \\
0 \\
0 \\
0 \\
115\end{array}$ & $\begin{array}{r}10 \\
20 \\
28 \\
21 \\
10 \\
1 \\
1 \\
24 \\
115 \\
741\end{array}$ & $\begin{array}{r}3 \\
9 \\
21 \\
14 \\
2 \\
1 \\
0 \\
9 \\
59 \\
741\end{array}$ & $\begin{array}{r}1 \\
3 \\
2 \\
3 \\
1 \\
0 \\
0 \\
4 \\
14 \\
115\end{array}$ & $\begin{array}{r}0 \\
1 \\
2 \\
2 \\
1 \\
0 \\
0 \\
2 \\
8 \\
115\end{array}$ \\
\hline $\begin{array}{l}\text { affected relatives } \\
\% \text { of families with }\end{array}$ & $127 \ddagger$ & 4 & 3 & 0 & 90 & 46 & 12 & 8 \\
\hline affected relatives & $17 \cdot 3$ & 0.5 & $2 \cdot 6$ & $0 \cdot 0$ & $12 \cdot 1$ & $6 \cdot 2$ & $10 \cdot 4$ & $7 \cdot 0$ \\
\hline
\end{tabular}

${ }^{*}$ Information about total number of relatives was available for parents and sibs only. They are as follows. (1) Parents: $\mathrm{CL} \pm \mathrm{P}$ cases and controls, 1480; CP cases and controls, 230. (2) Sibs: $C L \pm P$ cases, 1270; controls, 1003; CP cases 170, controls, 138.

†32 sibships with one affected, one with two affected, and one with three affected, besides the proband.

fOne family with two probands (twins).

Type and degree of genetic determination were estimated according to Czeizel and Tusnady ${ }^{12}$ and Emery. ${ }^{17}$ Further details about this sample have been presented elsewhere. ${ }^{15} 16$

\section{Results}

Table 1 shows the prevalences of the same type or of different types of malformation among relatives of the probands and those of appropriate controls. The following points should be stressed. (1) The frequency of familial cases of $C L \pm P$ was $17 \cdot 3 \%$, compared to $0.5 \%$ of subjects with this malformation among the families of controls. The corresponding figures for $\mathrm{CP}$ show a less marked difference $(2 \cdot 6 \% v 0 \cdot 0 \%)$. (2) If only subjects who share $50 \%$ of their genes with the probands are included, it will be seen that the frequency of $C L \pm P$ among the sibs of newborn babies with this malformation $(37 \times 100 / 1270=2.9 \%)$ is significantly higher than that present among their parents $(24 \times 100 / 1480=1.6 \% ; \mathrm{p}<0 \cdot 02)$. (3) The frequency of other malformations is also significantly raised in the families of $C L \pm P$ probands, as compared to those of controls $(12 \cdot 1 \% v 6 \cdot 2 \% ; p<0.02)$, but not among the families of CP probands (10.4 $v 7 \cdot 0 \%)$. (4) The prevalence of other malformations is higher $(p<0.05)$ among the sibs $(20 \times 100 / 1270=1.6 \%)$ than the parents $(10 \times 100 / 1480=0.7 \%)$ of $C L \pm P$ probands.

Additional analyses can be made in the larger $C L \pm P$ series, but even there sample sizes prevent separate analyses of parents and sibs. Therefore, they are grouped together as first degree relatives, as other authors have done; the results are given in table 2 . The difference in frequency between the prevalence of this malformation among first degree relatives of $\mathrm{CL} \pm \mathrm{P}$ male $(1 \cdot 8 \%)$ and female $(2 \cdot 8 \%)$ probands is as expected for a model of multifactorial inheritance with different thresholds for the manifestation of the
Table 2 Prevalence of the same malformation among first degree relatives of different types of $C L \pm P$ probands.

\begin{tabular}{lcccc}
\hline \multirow{2}{*}{$\begin{array}{l}\text { Types of } \\
\text { probands }\end{array}$} & \multicolumn{3}{c}{ First degree relatives } \\
\cline { 2 - 4 } & No & Affected & Total & Percentage \\
\hline Males & 447 & 29 & 1591 & $1 \cdot 8$ \\
Females & 294 & 32 & 1159 & $2 \cdot 8$ \\
Total & 741 & 61 & 2750 & $2 \cdot 2$ \\
CL only & 236 & 17 & 841 & $2 \cdot 0$ \\
CL+P & 505 & 44 & 1909 & $2 \cdot 3$ \\
Unilateral CL & 201 & 15 & 723 & $2 \cdot 1$ \\
Bilateral CL & 17 & 4 & 53 & $7 \cdot 5$ \\
Unilateral CL+P & 332 & 26 & 1305 & $2 \cdot 0$ \\
Bilateral CL+P & 132 & 12 & 308 & $3 \cdot 9$ \\
\hline
\end{tabular}

For 59 probands there was no information on whether the malformation was uni- or bilateral.

malformation in the two sexes, but the difference is not significant. The comparison of prevalence between the relatives of probands with $C L$ only and $C L+P$ also yielded non-significant results, but the relatives of unilateral CL had a lower prevalence of the malformation $(2 \cdot 1 \%)$ than those of bilateral $\mathrm{CL}$ cases $(7.5 \% ; p<0.01)$, the same being true when unilateral and bilateral $\mathrm{CL}+\mathrm{P}$ probands are considered $(2 \cdot 0 \% v$ $3.9 \%$; $<0.05$ ).

A search was conducted to verify if, among the other malformations present in the relatives of $C L \pm P$ or CP babies, the head region was more often affected than other parts of the body. However, this was not found to be the case. Neural tube or other fusion defects were not particularly frequent either.

The degree of genetic determination of $\mathrm{CL} \pm \mathrm{P}$ can be estimated by comparing the frequency of the malformation among first degree relatives of the probands $(2 \cdot 2 \%)$ with that obtained in the total sample $(0 \cdot 87) .{ }^{15}$ Using a graph constructed by C A B Smith and reproduced in Emery, ${ }^{17}$ which considers the relationships between these frequencies and the 
parameter considered, we arrived at an estimate of $70 \%$. It is also possible to calculate the degree of genetic determination using another method, ${ }^{12}$ but the value obtained $(74 \%)$ is similar to that reached by the first method. By dividing the prevalence among first degree relatives by that found in the general population we obtain a value (named $\mathrm{K}$ by Penrose in $1953^{17}$ ) which can serve as a rough indicator of the mode of inheritance of a given characteristic. For $\mathrm{CL} \pm \mathrm{P}$ the number obtained was $33 \cdot 3$, almost identical to that expected under a model of multifactorial inheritance 33.9 ; the number expected for an autosomal dominant gene would be much higher: $574 \cdot 7$ ).

For cleft palate alone the numbers do not justify the performance of such calculations. Taken at face value, however, the presence of one affected by the same malformation among the first degree relatives of the $\mathrm{CP}$ probands yields a frequency of $1 \times 1000 / 230$ parents +170 sibs $=2 \cdot 5 \%, 19 \cdot 2$ times higher than the population prevalence of $0 \cdot 13 \% .{ }^{15}$

\section{Discussion}

The estimates of the degree of genetic determination obtained here for $C L \pm P(70$ to $74 \%$ ) are very close to those found in two European countries, in the United States, and in China (74 to 79\%; comparison restricted to samples in which more than one category of relatives was compared with the general population). 568911 This similarity, observed in such variable environments, suggests that the real figure should be within the interval provided by these studies.

As for the differences found in the prevalences of $\mathrm{CL} \pm \mathrm{P}$ in relatives of different $\mathrm{CL} \pm \mathrm{P}$ probands, table 3 compares the results reported here with those obtained previously in different studies. In all cases the present figures are within the range of those encountered in earlier surveys, although it should be mentioned that sometimes this range is quite wide.

Table 3 Prevalence of $C L \pm P$ among first degree relatives of different types of $C L \pm P$ probands: comparison among series.

\begin{tabular}{|c|c|c|c|c|}
\hline \multirow[b]{3}{*}{$\begin{array}{l}\text { Types of } C L \pm P \\
\text { probands }\end{array}$} & \multicolumn{4}{|c|}{ Frequency in first degree relatives (\%) } \\
\hline & \multirow[b]{2}{*}{$\begin{array}{c}\text { Present } \\
\text { study }\end{array}$} & \multicolumn{3}{|c|}{ Previous studies $^{4-7}$} \\
\hline & & $\begin{array}{l}\text { No of } \\
\text { series }\end{array}$ & Average & Range \\
\hline $\begin{array}{l}\text { Males } \\
\text { Females } \\
\text { CL only } \\
\text { CL+P } \\
\text { Unilateral CL } \\
\text { Bilateral CL } \\
\text { Unilateral CL+P } \\
\text { Bilateral CL+P }\end{array}$ & $\begin{array}{l}1 \cdot 8 \\
2 \cdot 8 \\
2 \cdot 0 \\
2 \cdot 3 \\
2 \cdot 1 \\
7 \cdot 5 \\
2 \cdot 0 \\
3 \cdot 9\end{array}$ & $\begin{array}{l}5 \\
5 \\
7 \\
7 \\
5 \\
3 \\
5 \\
5\end{array}$ & $\begin{array}{l}2 \cdot 8 \\
3 \cdot 1 \\
2 \cdot 6 \\
2 \cdot 9 \\
2 \cdot 2 \\
4 \cdot 0 \\
3 \cdot 4 \\
4 \cdot 7\end{array}$ & $\begin{array}{l}1 \cdot 2-4 \cdot 0 \\
1 \cdot 9-3 \cdot 8 \\
2 \cdot 0-4 \cdot 3 \\
1 \cdot 3-3 \cdot 9 \\
1 \cdot 0-2 \cdot 7 \\
0 \cdot 0-8 \cdot 3 \\
1 \cdot 3-4 \cdot 2 \\
1 \cdot 4-6 \cdot 6\end{array}$ \\
\hline
\end{tabular}

The lack of difference in the number of affected relatives of $C L$ as compared to $C L+P$ subjects has also been found elsewhere, the averages of these previous investigations $(2.6 v 2.9)$ being similar to those reported here $(2.0 v 2.3)$. This is evidence against the multifactorial model, but all the other comparisons favour it, as well as the different thresholds of males and females. The recently reported association between two restriction fragment length polymorphisms at the transforming growth factor alpha locus and the occurrence of $C L \pm P^{18}$ is interesting in this regard. Confirmation or refutation of this finding may be decisive in the search for the elusive major gene that could influence the liability to this complex malformation. Other recent analyses ${ }^{19} 20$ suggest that the effects of a major gene should not be ignored.

We have found that the frequency of $C L \pm P$ is higher among sibs $(2.9 \%)$ as compared to parents $(1 \cdot 6 \%)$ of $C L \pm P$ probands. Similar results were observed in the majority of previous studies, ${ }^{5-7} 122122$ but there are two conflicting reports. ${ }^{23} 24$ Two explanations can be advanced for this difference: (1) reduced viability of $C L \pm P$ subjects, or (2) action of dominant genes in the background of such subjects. ${ }^{25}$

The prevalence of other malformations was two times higher in the families of $C L \pm P$ probands than in those of the controls. This was not observed by Czeizel and Tusnady, ${ }^{12}$ who found similar frequencies in these two groups. On the other hand, Fraser et al ${ }^{14}$ encountered a high frequency of neural tube defects among the sibs of $C L \pm P$ subjects, and Khoury et al ${ }^{13}$ observed a high incidence of $C L \pm P$ in the sibships of probands with neural tube defects without other associated malformations. Both anomalies are more commonly found in spontaneous abortions than in livebirths. Therefore, the association could result from a diminished capacity of certain mothers to reject determined types of malformed embryos, or, alternatively, from a uterine, familial, environmental, or genetic embryonic factor that would increase the probability of various fusion defects. ${ }^{14}$ It should be noted, however, that in our series neural tube or other fusion defects were not overrepresented. We are left, therefore, with two other explanations for the findings reported here: (1) a general susceptibility to malformations in the families of $C L \pm P$ subjects; or (2) differing recall among the mothers of affected babies compared to those of normal babies. Against the second alternative is the fact that no significant differences regarding these frequencies were found in the families of CP and normal newborn children.

Finally, the two times higher prevalence of other malformations among sibs as compared to parents of $C L \pm P$ children could be explained by the fact that the former had not yet been completely subjected to the action of natural selection, as had the subjects of the earlier generation. 
We would like to thank Drs Ieda M Orioli and Eduardo E Castilla for providing us with the ECLAMC data, as well as for valuable suggestions on the data analysis.

1 Fogh-Andersen P. Inheritance of harelip and cleft palate. Copenhagen: A Busck, 1942.

2 Bear JC. Liability to cleft lip and palate. Interpreting the human data. Issues Rev Teratol 1988;4:163-204.

3 Fraser FC. Mapping the cleft-lip genes: the first fix? Am $\mathrm{f} \mathrm{Hum}$ Genet 1989;45:345-7.

4 Fraser FC. The genetics of cleft lip and cleft palate. Am f Hum Genet 1970;22:336-52.

5 Carter CO, Evans K, Coffey R, Fraser Roberts JA, Buck A, Fraser Roberts M. A three generation family study of cleft lip with or without cleft palate. $\mathcal{J}$ Med Genet 1982;19:246-61.

6 Melnick M, Bixler D, Fogh-Andersen P, Conneally PM. Cleft lip \pm cleft palate: an overview of the literature and an analysis of Danish cases born between 1941 and 1968. Am 7 Med Genet 1980;6:83-97.

7 Tenconi R, Clementi M, Turolla L. Theoretical recurrence risks for cleft lip derived from a population of consecutive newborns. F Med Genet 1988;25:243-6.

8 Woolf CM. Congenital cleft lip: a genetic study of 496 propositi. $\mathcal{F}$ Med Genet 1971;8:65-82.

9 Carter $\mathrm{CO}$. Genetics of common single malformations. $\mathrm{Br}$ Med Bull 1976;32:21-6.

10 Bear JC. A genetic study of facial clefting in northern England. Clin Genet 1976;9:277-84.

$11 \mathrm{Hu} \mathrm{D,} \mathrm{Li} \mathrm{J,} \mathrm{Chen} \mathrm{H,} \mathrm{et} \mathrm{al.} \mathrm{Genetics} \mathrm{of} \mathrm{cleft} \mathrm{lip} \mathrm{and} \mathrm{cleft} \mathrm{palate} \mathrm{in}$ China. Am $\mathcal{F}$ Hum Genet 1982;34:999-1002.

12 Czeizel A, Tusnady G. A family study on cleft lip with or without cleft palate and posterior cleft palate in Hungary. Hum Hered 1972;22:405-14.

13 Khoury MJ, Erickson JD, James LM. Etiologic heterogeneity of neural tube defects. II. Clues from family studies. Am $\mathrm{F} \mathrm{Hum}$ Genet 1982;34:980-7.

14 Fraser FC, Czeizel A, Hanson C. Increased frequency of neural tube defects in sibs of children with other malformations. Lancet 1982;ii:144-5.

15 Menegotto BG, Salzano FM. Epidemiology of oral clefts in a large South American sample. Cleft Palate $\mathcal{f}$ (submitted).

16 Menegotto BG, Salzano FM. A new study on the relationship between oral clefts and fetal loss. Am 7 Med Genet (in press).

17 Emery AEH. Methodology in medical genetics: an introduction to statistical methods. Edinburgh: Churchill Livingstone, 1976.

18 Ardinger HH, Buetow KH, Bell GI, Bardach J, VanDemark DR, Murray JC. Association of genetic variation of the transforming growth factor-alpha gene with cleft lip and palate. Am $\mathbf{f ~ H u m}$ Genet 1989;45:348-53.

19 Chung CS, Beechert AM, Lew RE. Test of genetic heterogeneity of cleft lip with or without cleft palate as related to race and severity. Genet Epidemiol 1989;6:625-31.

20 Ward RE, Bixler D, Raywood ER. A study of cephalometric features in cleft lip-cleft palate families. I. Phenotypic heterogeneity and genetic predisposition in parents of sporadic cases. Cleft Palate 7 1989;26:318-26.

21 Welch J, Hunter AGW. An epidemiological study of facial clefting in Manitoba. $\mathcal{f}$ Med Genet 1980;17:127-32.

22 Marazita ML, Spence MA, Melnick M. Major gene determination of liability to cleft lip with or without cleft palate: multiracial view. F Craniofac Genet Dev Biol 1986;2:89-97.

$23 \mathrm{Knox} G$. The family characteristics of children with clefts of lip and palate. Acta Genet Stat Med 1963;13:299-315.

24 Bear JC. Spontaneous abortion, sex ratio and facial cleft malformation. Clin Genet 1978;13:1-7.

25 Cavalli-Sforza LL, Bodmer WF. The genetics of human populations. San Francisco: Freeman, 1971. 